\title{
Social Media Readiness in Public Administration Developing a Research Framework
}

\author{
Christian Pieter Hoffmann, Christoph Lutz, Miriam Meckel \\ University of St. Gallen - Institute for Media and Communications Management
}

\begin{abstract}
This paper develops a multi-level model of Social Media Readiness (SMR) in public administration. Social Media Readiness is described as the extent to which an individual, group or organization is willing, able and prepared to use social media for professional purposes. We survey literature that potentially informs our understanding of SMR. In order to develop a model that is both tailored to the specific context of public administration, and sufficiently represents the complexity of the phenomenon, we conducted an explorative study in late 2011, based on eight case studies within a German state administration. We analyzed social media initiatives in order to identify antecedents of SMR based on the perspectives and experiences of public employees involved in such projects. Finally, we substantiate the resulting model based on established theories of technology acceptance, digital divide, trust, innovation diffusion and public entrepreneurship in order to propose a, both, empirically and theoretically founded framework for future research into social media readiness in public administration.
\end{abstract}

\section{Introduction: Why Social Media Readiness?}

Various studies have explored the impact of new media on the interaction of governments and their citizenry (e-government) or the engagement of citizens in questions of governance (e-governance) (Albrecht et al., 2008; Andersen et al., 2011; Bannister \& Connolly, 2012; Ebbers et al., 2008; Gauld et al., 2010; Grönlund, 2010; Heeks \& Bailur, 2007; Höchtl et al., 2011; Rossel \& Finger, 2007). New communication technologies, like social media, are held to make citizen participation in public governance logistically feasible by supporting deliberative processes and providing access to a wide range of information as well as online conversations (White, 1997; DiMaggio et al., 2001; Stromer-Galley \& Foot, 2002). More and 
more, public administrations strive to employ social media in their interactions with the overall public and individual citizens (Mergel, 2010; 2012). Yet, little is known about the necessary preconditions of professional social media use in public administration and the diffusion of social media in public administration settings in general: We only found sporadic evidence and few studies on social media use in public administration - and even fewer reliable numbers. As an exception, Criado and Rojas-Martin's (2012) study on social media in local governments of Spain revealed that on average regional governments have been working with social media for 2.78 years (as of 2012). Although all the Spanish governments have a social media presence, the personnel dedicated to its management varies greatly from only a handful of employees in Aragon and Extremadura to about 100 people in Pais Vasco (Criado \& Rojas-Martin, 2012, p. 12). Similar studies for other countries are missing and we did not find any quantitative account on how many public administrations in Germany actively use social media channels. However, one thing we do know: in order to be used, employees need to accept social media, i. e. they must be "social media ready".

The term "readiness" is applied to individual, organizational and social phenomena, and in fields as diverse as education research ("school readiness") or military analysis. Readiness typically describes a willingness, ability and/or preparedness for a particular action. Applied to the use of ICT, we find "e-readiness" as a concept for societies' preparedness to exploit the potentials of e-commerce or e-government (Molla \& Licker, 2005). On an individual level, ICT "readiness" is often associated with users' competencies, their propensity to trust and their technology acceptance (McKnight et al., 2002; Venkatesh et al., 2012). On an organizational level, "readiness" is a common term in the innovation and change literature (Rafferty et al., 2013), but it has also been applied to an organization's ability and preparedness to employ ICT innovations (Hameed et al., 2012). We define social media readiness (SMR) as the extent to which an individual, group or organization is willing, able and prepared to use social media for professional purposes.

Grönlund (2010, p. 23) recently described a "[...] need for new models to meet the contemporary and future challenges of eGovernment". It has been argued that e-government research still suffers from a lack of theory (Norris \& Lloyd, 2006). In a review of 99 articles in the field, Titah and Barki (2006, p. 47) did not find a single study addressing the multi-level 
and multi-dimensional nature of the e-government adoption process. This lack of complexity and depth in the emerging field of e-government research flies in the face of ever more complex implementation and management processes, especially given the new opportunities and challenges associated with social media. Recently, Lee and Kwak (2012) and Picazo-Vela et al. (2012) attempted to tackle the conceptual complexity and dynamics of social media use in public administration. Based on such initial insights, we set out to develop a model of Social Media Readiness that not only applies to the specific context of public administration, but identifies antecedents of social media use both on the organizational and individual level. Accordingly, our research question is: What are individual and organizational antecedents of social media readiness in public administration?

We will base our analysis on an overview of information systems and innovation theories that have the potential to inform our understanding of social media readiness. This overview reveals a need to incorporate insights into social media readiness on both an individual and organizational level of analysis. To that end, and in order to ensure the applicability of our findings to the context of public administration, we base the development of our model on an explorative study, conducted in the administration of a German state. We analyze a range of eight small case studies covering initiatives aimed at the introduction of social media into administrative processes. Chapter 3 will describe the study's methodology; chapter 4 will present its results. Finally, chapter 5 will tie our findings back into existing theory and substantiate our multi-level model of social media readiness based on technology acceptance, digital divide, trust, innovation diffusion and public entrepreneurship theories. We propose that our findings will contribute to theories of social media use in public administration by providing an empirically and theoretically founded framework for future research into social media readiness.

\section{Theory: Foundations of Social Media Readiness}

A range of theories have addressed constructs and relationships that influence social media readiness both on an individual and organizational level. We conducted a literature analysis in order to identify theories that could inform the development of a model of social media readiness in public administration. Information systems literature has come a long way in 
analyzing individual antecedents of ICT use or acceptance - but there is only little research on organizational drivers of ICT adoption. Here, innovation research provides a promising approach as several strands of theory have discussed organizational antecedents of product and process innovations, including the adoption of new ICT.

Within the IS and sociological field, digital divide research has addressed a number of individual antecedents of ICT use: demographic differences, such as age and gender, and socioeconomic status are held to structure individuals' attitudes and use of the Internet and web 2.0 technologies (Hargittai, 2007; Hargittai \& Walejko, 2008; Blank \& Reisdorf, 2012). Age and socioeconomic status have been shown to be strong predictors of Internet skills, usage and gratifications (Van Dijk, 2006, p. 226) - which also holds true for the more specific and interactive world of social media (Blank \& Reisdorf, 2012). Much of the digital divide literature focuses on private settings, however. Social media at the workplace and within business units, teams and complex organizations are not at the core of digital divide studies. Still, this research strand provides first insights into why certain public administration employees might be more ready to use social media than others: We would expect younger, more Internet-experienced, skilled and educated employees to exhibit a higher SMR than their older, less experienced, skilled and educated counterparts.

Another well-established approach to individual antecedents of ICT use is the Technology Acceptance Model (TAM) and its various derivations, such as TAM2, TAM3, UTAUT and UTAUT2 (Davis, 1989; Venkatesh \& Bala, 2008; Venkatesh \& Davis, 2000; Venkatesh et al., 2003; Venkatesh et al., 2012). Based on the Theory of Reasoned Action (Fishbein, \& Ajzen 1975), the Motivational Model (Davis et al., 1992), the Theory of Planned Behavior (Ajzen, 1991; Taylor, \& Todd, 1995), the Model of PC Utilization (Thompson et al., 1991), and the Social Cognitive Theory (Compeau, \& Higgins, 1995), technology acceptance models were able to show that the adoption of new technologies is strongly driven by the users' mental calculation of the technology's benefits and costs. As numerous empirical tests have shown, technology acceptance models explain approximately $40 \%$ of the variance in individuals' intention to use an ICT and actual usage (Venkatesh, \& Bala, 2008; Wang et al., 2003).

Technology acceptance models address both characteristics of the technology itself and user features. Davis (1989) argued that individual adoption and use of new ICT will take place if they are perceived as both useful and easy to use. In contrast to the digital divide approach, 
TAM has frequently been used to explain technology acceptance at the workplace. Therefore, it may provide applicable insights for public administration settings. Going beyond the digital divide approach, TAM directs our attention to the perception of technologies themselves: In our case, we would expect that, when public administration employees perceive social media as complicated, not useful and not fitting into their work environment, they are not likely to be ready to use them.

Recent studies have investigated innovations and their diffusion under a social network lens, e.g. by employing contagion models (Dodds \& Watts, 2005; Watts \& Dodds, 2007). The social capital perspective and the role of hubs in the diffusion process are other avenues within the network paradigm (Goldenberg et al., 2009; Iyengar et al., 2011). In such a relational perspective, we would expect well-connected people to get more and earlier exposure to a new technology and therefore be more likely to adopt. The same should hold true for social media in public administration: The more open-minded and social mediasavvy public administration employees' immediate contacts are, the readier the employees themselves should be to adopt new instruments as well.

Other theories have focused on organizational behavior and change when addressing technology readiness. Such theories aim at explaining why certain organizations adopt new technologies while others do not. Under an institutional perspective, isomorphistic tendencies are crucial in explaining organizational change and the diffusion of innovations (DiMaggio \& Powell, 1983). Once certain organizations have adopted ICTs, such as social media, others may jump on the bandwagon and feel pressured to also adopt the new technology, even when they might not see its immediate advantage. Taking this theory as a starting point, we would expect mimetic and normative pressures, once a larger part of public administrations has adopted social media within their work routines. Several authors analyzed the diffusion and assimilation of organizational information systems based on institutional theory (Purvis et al., 2001; Teo et al., 2003). However, although the institutional approach is able to account for the spread of ICTs once they have already been adopted by pioneer organizations, it fails to explain initial technology readiness.

In more descriptive terms, Rogers (1995) addressed the question of how a diffusion of innovations (DOI) takes place. He differentiates five types of adopters according to the time when they decide to adopt an innovation: innovators, early adopters, early majority, late 
majority and laggards. Furthermore, he proposes that five properties of the innovation itself shape its popularity: relative advantage, compatability, complexity, observability and trialability (Moore \& Benbasat, 1991, p. 195). Within the DOI framework, individual characteristics (such as attitudes toward change), organizational antecedents (centralization, complexity, size etc.) and external ones come together and shape organizational innovativeness (Oliveira \& Martins, 2011). Thus, the DOI approach presents a relatively holistic framework for analyzing technology adoption. However, it is geared at explaining the actual adoption of innovations rather than the readiness to adopt and does not provide an explanation of how the different conceptual levels interrelate in this process.

Similar to the DOI approach is the "Technology-Organization-Environment" framework (TOE; Tornatzky \& Fleischer, 1990). It poses that three forces interplay and shape the adoption of new technologies in organizations: aspects and characteristics of the technology itself $(\mathrm{T})$, organizational attributes, such as its size and the sector it operates in $(\mathrm{O})$, and the environment (E), i. e. outside forces, such as state regulations and macroeconomic developments. The TOE framework has been applied for different information systems, such as Enterprise Resource Planning Software (Pan \& Jang, 2008), Electronic Data Interchange (Kuan \& Chau, 2001) and electronic business (Zhu et al., 2003). Results are generally mixed and organizational factors are somewhat better at predicting technology adoption than environmental influences. As the TOE-framework neglects individual aspects of technology readiness and adoption and focuses on whole organizations - especially in the private sector-, we consider it not a very suitable model for our purpose.

In summary, our theory overview shows that a range of different research strands seem promising in informing a framework of social media readiness in public administration. Still, we identify two challenges in deriving such a framework exclusively from existing theories: (I) Only few theories provide a multi-level approach to technology readiness: while IS research largely focusses on individual antecedents, innovation research is primarily concerned with organizational factors. A strong rationale is necessary to combine findings from both areas in order to avoid eclecticism. (II) Overwhelmingly, the theories surveyed in this review address private sector settings, only rarely do studies adapt their models to public administrations. It therefore seems necessary to base a model of social media readiness in public administration on insights generated in this particular context. We 
therefore propose an explorative research approach by basing our multi-level model of social media readiness on empirical insights generated in a public administration setting, which we will then substantiate by available IS and innovation theories.

\section{Methodology: An Explorative Case Study Approach}

We chose to employ an interpretative research paradigm, using grounded theory (Denzin, 1983; Glaser \& Strauss, 1967; Strauss \& Corbin, 1998). The purpose of our study was to explore the issue at hand from the perspectives of the professionals involved and in the environment in which they occur (Denzin \& Lincoln, 1994). We were especially interested in the experiences, understandings and narratives of the public employees involved in social media initiatives. Therefore, in late 2011, we conducted 8 small case studies, all within the administration of a German state. The cases covered a majority of all social media initiatives within the state administration during the previous 12 months (a total of 11 initiatives). The case selection followed the theoretical sampling strategy recommended by Glaser and Strauss (1967), according to which the researcher conducts an iterative process of data collection, coding and analysis, leading to decisions on the necessity and type of additional data, until theoretical saturation is reached.

In this case, additional cases were added to the sample representing successful and unsuccessful initiatives, initiatives within central state agencies and agencies with a regional focus, and finally key administrative functions as well as a public-private partnership and publicly held private entities - all with the aim of elaborating characteristics and dimensions of the emerging concepts. All case studies were based on semi-structured interviews with the responsible project managers and, in a few cases, employees involved in the decision-making process (11 interviews altogether). The decision to include additional employees in the interviews was made by the project managers based on their operative involvement. We complemented the case studies with extensive, repeat interviews with representatives of the state's central service department overseeing all IT and e-government projects. The latter interviews served to validate and contextualize the case studies. Table 1 provides an overview of the case studies. 


\begin{tabular}{|c|c|c|}
\hline Identifier & Organizational Unit & Description \\
\hline $\mathrm{I} 1$ & Human Resources Agency & $\begin{array}{l}\text { The agency had decided to employ social networking sites for } \\
\text { recruitment purposes. At the time of the interviews, the } \\
\text { project was already at an advanced stage and only few } \\
\text { months away from launch. } \\
\text { Two employees responsible for the project were interviewed. }\end{array}$ \\
\hline $\mathrm{I} 2$ & $\begin{array}{l}\text { Environmental and } \\
\text { Development Agency }\end{array}$ & $\begin{array}{l}\text { The agency had decided to promote a specific local event } \\
\text { through social media channels. The event was already } \\
\text { nearing its close. The use of both Facebook and Twitter had } \\
\text { been realized by the employee in charge, in close cooperation } \\
\text { with the state's Web service provider. The employee in } \\
\text { question had been hired from the private sector specifically } \\
\text { for the event. The future use of the social media channels } \\
\text { remained uncertain at the time of the interview. }\end{array}$ \\
\hline I3 & $\begin{array}{l}\text { Agency for Culture and } \\
\text { Sports }\end{array}$ & $\begin{array}{l}\text { The agency had contemplated using social media for the } \\
\text { communication of its activities to the general populace. After } \\
\text { some deliberation within the organization, a decision was } \\
\text { taken to abstain from social media use. } \\
\text { The responsible manager and two involved employees were } \\
\text { interviewed. }\end{array}$ \\
\hline I4 & District Administration A & $\begin{array}{l}\text { Employees of the administration had proposed to employ } \\
\text { social media in a local youth engagement project. The project } \\
\text { leader had been pursuing the proposition for more than a } \\
\text { year. At the time of the interview, realization remained } \\
\text { uncertain. }\end{array}$ \\
\hline I5 & District Administration B & $\begin{array}{l}\text { The administration's head had asked the head of the } \\
\text { communication department to start a Facebook presence for } \\
\text { the administration. The site had been realized as a side } \\
\text { activity within the communication department. Because of } \\
\text { political considerations within the state administration, it was } \\
\text { deactivated after approx. } 5 \text { months later. }\end{array}$ \\
\hline I6 & $\begin{array}{l}\text { Provider of Web Services } \\
\text { (public-private partnership) }\end{array}$ & $\begin{array}{l}\text { The service provider had started promoting the state's official } \\
\text { website and its content through both Facebook and Twitter } \\
\text { more than a year prior to the interviews. It was inviting state } \\
\text { agencies to share content through these channels as well. } \\
\text { Topics were to be selected and redacted by the website editor. }\end{array}$ \\
\hline I7 & $\begin{array}{l}\text { Regional Marketing Agency } \\
\text { (publicly held private entity) }\end{array}$ & $\begin{array}{l}\text { The Marketing Agency actively employs social media to } \\
\text { promote the state's tourist attractions and investment } \\
\text { opportunities through Twitter, Facebook and YouTube. }\end{array}$ \\
\hline I8 & $\begin{array}{l}\text { Agency for the Promotion of } \\
\text { Economic Development } \\
\text { (publicly held private entity) }\end{array}$ & $\begin{array}{l}\text { The agency promotes its services through channels such as } \\
\text { Facebook, Twitter, Vimeo and Flickr. }\end{array}$ \\
\hline
\end{tabular}

Table 1: Case Studies 
In each case, the interview guideline addressed a specific project aimed at introducing social media into an administrative unit's communication processes. Questions covered the aim, instruments and resources of the project, its initiator(s), participants and their motivations, responsibilities, driving forces, perceived chances and risks, decision processes, hurdles, the participants' personal background, ICT use experience and attitudes towards social media, and finally, where applicable, a comparison between private corporations and public administration. Each interview lasted approximately one hour, was recorded and later transcribed.

The interviews were conducted in the participants' offices - the research team took careful note of the physical environment, the atmosphere within the various departments, and the climate between the involved team members. By relying on personal introductions provided by previous interview partners, and by ensuring the interview partners' anonymity, the team managed to create an open, trustful interview atmosphere. The interview partners were remarkably candid in addressing perceived obstacles to social media use and in criticizing circumstances perceived as unhelpful to the introduction of social media - or proposing necessary changes within the organization.

The interview analysis was based on Atlas.ti and conducted by at least two members of the research team independently. In the coding process, all statements referring to drivers, prerequisites and motivations of social media use as well as obstacles, apprehensions or resistance were tagged and labeled. Similar descriptions were then grouped under the same category (Strauss \& Corbin, 1998). These initial categories were applied to subsequent interview transcripts (axial coding). Finally, the emerging categories were refined and integrated into theoretical concepts, resulting in 12 antecedents of social media readiness (selective coding). The following segments will present the resulting categories, differentiated by the level of their occurrence: individual or organizational phenomena.

\section{Results: Antecedents of Social Media Readiness}

Our analysis resulted in a multi-level model that includes five organizational and seven individual antecedents of social media readiness (see Figure 1). We propose that combined, these elements provide for a valid model of social media readiness in public administration, 
which we conceptualize as a predictor of actual social media use. The following segments will briefly describe the identified antecedents, differentiated by the individual and organizational level of observation.

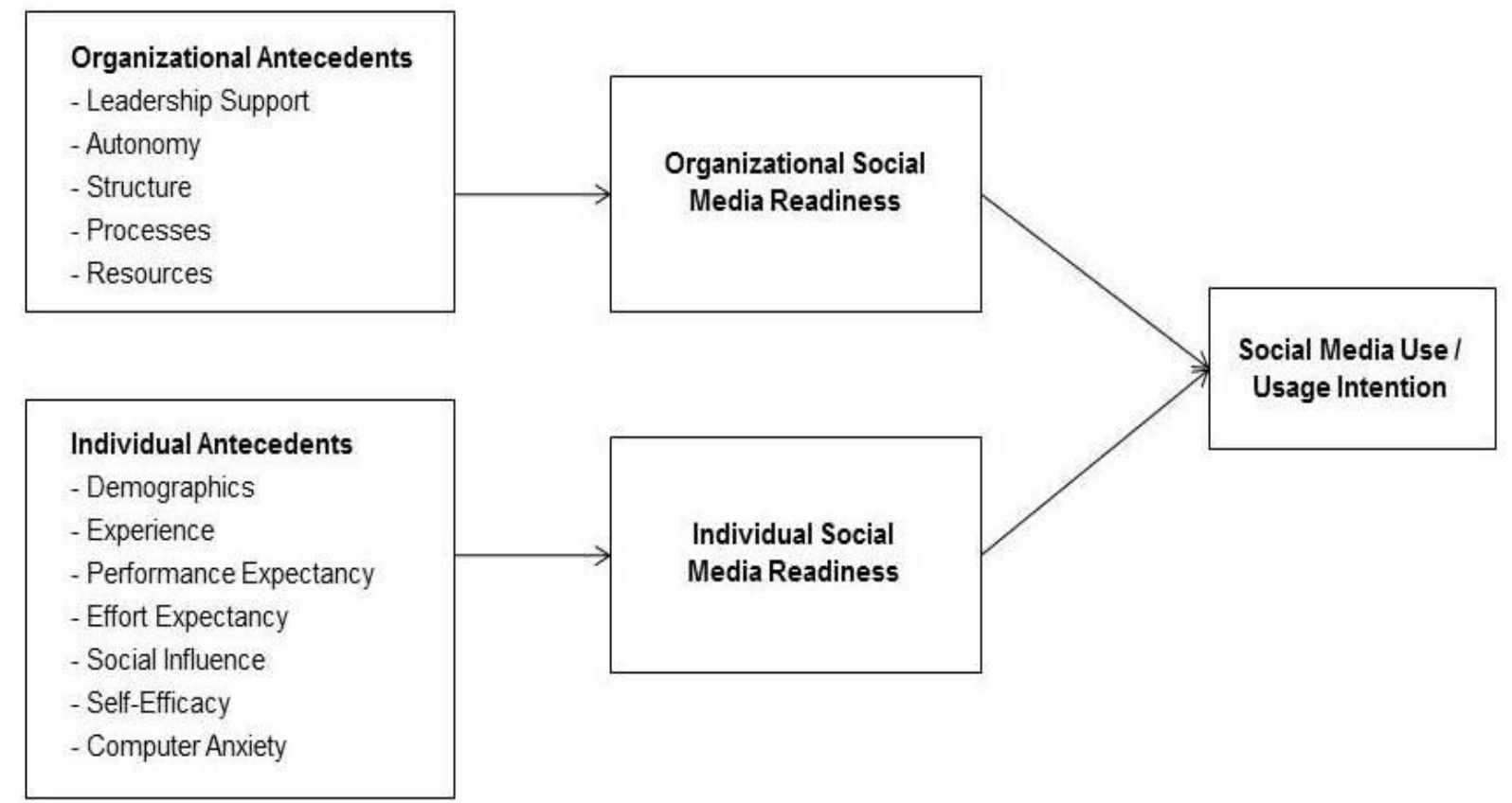

Figure 1: Multilevel Model of Social Media Readiness

\subsection{Individual Level}

\section{Demographics}

Many interview partners speculated that age or generational differences play an important role in the success of social media projects. It was proposed that younger employees have more experience with social media and are therefore more open to their use. At the same time, the average age within the public administration was judged to be quite high, making it a somewhat resistant environment.

«The director is the oldest one of us. That has to do with generation to some extent, it is somewhat of a generational question. He uses, I believe, no social media at all, I'd say.» (I8)

«It's a generational question, that's very obvious, some aren't interested at all, others are absolutely interested.» (I3)

«Our administration has an average age of 47. Here, people work until they're 63, 65, you don't have that in the private sector. Our decision makers are somewhere beyond 55.» (I1) 


\section{Experience}

Similar to the question of generational experience and openness, individual experience with social media emerged as an important influencing factor. Some interview partners had worked with social media in previous occupations, sometimes in the private sector. These employees regarded social media as an easy-to-use tool which provides little to no challenges.

"I myself also have a Facebook page. So the Facebook page that I created here [at work] would be my second page.» (I5)

At the same time, we found a surprising number of employees who had no personal experience with social media and who didn't use social media for private purposes either this seemed surprising in that all of them were involved in social media initiatives. In general, skepticism was notably high, as were fears regarding privacy and security protection on the web.

"You don't find a department head under the age of 40. So you don't have any Digital Natives, those are all Immigrants.» (I1)

«I am a very passive Facebook user. I'm irritated by everything that's revealed about me. I also think it's an information overload. There are so many things that I don't want to know that just kind of overwhelm me.»(I3)

\section{Performance Expectancy}

The question of whether social media are a useful tool in public administration was quite contended among our interview partners. Some participants were enthusiastic in their evaluation of social media tools. Others had difficulty identifying a convincing "business case" for their implementation.

"I use it myself, that's how I came up with the idea that it would make sense, because I communicate with my contacts via Facebook a lot. That really makes it much faster.» (I5)

«We have all these budget restrictions right now. So why is this an important task? We don't get it.» 
«We don't have much interaction with citizens. So the question really was, what content, I mean with what content can we keep a Facebook presence alive?» (I3)

Advantages mentioned by our interview partners included simplified interaction between citizens and public administration, providing information and outreach. Dangers or disadvantages identified by our interview partners included the increased susceptibility of the administration to public criticism, and privacy and security concerns. Some participants referred to perceived high quality standards in the organization concerning communication with the public, some of which based on legal requirements, that are ensured by complex quality assurance mechanisms. They doubted whether these same quality standards could be transferred to social media.

\section{Effort Expectancy}

Again and again, participants addressed a certain fear that social media might be associated with additional workloads. Keeping social media profiles up-to-date was considered quite time-consuming. An increased workload was one of the most frequently mentioned dangers of social media use. This included the necessity to navigate complicated organizational structures and coordination processes. These fears were most dominant in those cases that did not (yet) implement any social media tools.

"I don't have time to sit in front of the screen even longer. I mean, I always sit here for a long time, and then I don't want to do more of same, maybe even at home.» (I1)

"To many, the topic is somewhat suspect, because they don't do it privately - and if they do, they are afraid because it would mean more work.» (I1)

\section{Social Influence}

Peer pressure was frequently quoted as a reason to use social media - both on an individual and organizational level.

«I suddenly realized that very many people communicate in social networks. People who never called us before suddenly contact us because they have questions or problems. It seems to be less of a hurdle to contact us on Facebook.» (I5) 
At the same time, social influences can also lead to adverse reactions and the avoidance of social media, especially if peers had made negative experiences.

«Well, this, let's say this pressure, suddenly everyone wants to be your friend, even though you have never seen them, that's not my thing.» (I3)

"Those in my circle of friends who have kids in their teens or so, who have made negative experiences, they also asked themselves: what's the point after all? In the end, it really isn't very useful, so you really start to think about it.» (I1)

\section{Self-Efficacy}

Interviewees' perceived self-efficacy emerged as an important factor in their openness regarding new ICT, their willingness to experiment with new tools. Self-efficacy thereby appears to be closely related with a personal affinity to innovative ICT and actual use experience.

«I just have a higher IT-affinity because of my previous position at [a private company]. I am one of those people that always play with their Blackberry and always have to discipline themselves.»(I1)

Self-efficacy seemed especially high in cases of experienced users, who showed little resistance to apply their know-how to work-related ICT projects.

«Training comes from practicing, I think. So the more you use social media, the more skilled you become, the more you know about it.» (I3)

«We looked around how we could manage it with our personnel, and finally I just said, ok, I'll do it, if necessary from my home. I have some experience.» (I5)

\section{Computer Anxiety}

A large number of interview participants did not use social media for private purposes. Very often, privacy and security concerns were quoted as inhibitors of social media use. This was also transferred to professional tasks: the question of how the high privacy standards of the administration could be ensured in a social media setting seemed to puzzle many project 
managers. This may partly be due to critical press coverage about social media providers and the critical stance of German data protection commissioners regarding social media.

«I don't want to be found [on the Internet].» (I4)

«I do everything not to be traceable online. (...) It's just to private for my taste. I prefer to look people in the eye, rather than on a screen. I don't think I've missed very much.» (I1)

"The state is quite conservative. Luckily, we excluded Facebook from our options early on because I think, at the moment, it would have been very difficult to gain acceptance for that, given all the recent headlines.» (I1)

\subsection{Organizational Level}

\section{Leadership Support}

Employees feel they need the support of their superiors in order to successfully realize social media projects. In the case of public administration, leadership support encompasses both political backing and support provided by the administrative leadership. In some cases, political backing was questioned by our interview partners, as some social media projects might create political attention, possibly even critical scrutiny, which should best be avoided. «We came up with the idea because our boss confronted us with it. But also members of parliament on the state and national level.» (I5)

"This can be a touchy subject because no politician wants to stumble over something like this, they tend to be very careful, because really, what can you win with an initiative like this?» (I1)

Again and again, leadership support was questioned because of the experience and preferences of the people in charge.

«...[] in our department, the leadership people are somewhat beyond 55. They know Facebook only, for example, because they opened an account in order to better survey their kids.» (I1)

«For the decision makers, let's put it that way, for the decision makers with whom I've talked, it is a relatively new area, where they haven't had much experience.» (I4) 
In some instances, political support was considered easier to realize than organizational support within the administration. In one case, an ongoing project was abandoned because of questionable support within the larger administration.

«Our MP, of course he's on Facebook (...) but this is a certain clientele and our [administrative leader], you won't find him on there.» (I1)

\section{Autonomy}

Autonomy or work discretion emerged as an element especially conducive to successful social media initiatives. On the one hand, projects driven by self-confident project managers in a very pro-active, independent manner, constituted the majority of successful implementation.

«Oh you know, we just did it.» (I2)

«I am quite glad that I'm directly subordinate to the department head, so I don't have to go through all the hierarchies. If you really have to stick to all the rules... but in this instance we said we'll just try it.» (I5)

Also, the specific features of social media are held to require an extended degree of autonomy - status updates or tweets cannot be checked and controlled by countless parties within the administration. Large degrees of autonomy are not regarded a typical feature of public administrations.

"I feel it's quite a luxury, I enjoy here - that I, just one person, can think up a solution, the fact that I have the liberty to propose something, to design something and invest a lot into it, just the way I think is right, the way I need it to come up with good results.» (I1)

On the other hand, we encountered very little complaints about suffocating restrictions, or even fear of repercussions. Rather, complicated, collaborative decision making processes are simply considered "modus operandi" in the public setting.

"There is no fear that some employee might post something that isn't good for the city or so. That's not it.» (I1) 


\section{Structure}

A striking element of the interviews was the repeated long-winding explanations of the organizational structures, the departments at various levels that needed to be involved into social media projects. Also, the coordination within and between agencies - in order to establish a social media presence or to use it - was described as quite challenging and complicated. In one instance, an interview partner needed more than 500 words just to describe the decision making process he had encountered so far.

«They thought we would create a completely independent social media presence, apart from the state's, and that's not possible within this structure. As a district or whatever unit, we can't just say we create another homepage. That's not possible.» (I4)

"The office has several special departments and internal affairs departments and it would be nice if they release their information to us. They could give them to me and I'd put them online. But you would probably need a specified contact person in every single department who is in charge of their particular topics.» (I5)

"There is the IT department, the press office of the agencies, I think, or the PM. Those are the superstructures, those responsible for the state's website. I asked those guys very early on. But then there are some IT people that knew and some that didn't, someone I forgot to CC. Typical. Oh, an then there is the press office of our agency, those I also involved from the beginning. And then there are the people over in the agency for e-government, whom I informed.» (I2)

In many instances, there are no established channels of communication between agencies on various levels. A cautious stance, a tendency to involve as many interested parties as possible - rather than accidentally keep one out of the loop - dominated most projects. In several cases, our interview partner complained about a lack of coordination between their unit/agency and projects of other, related unites.

"[...] but I need the consent of the agency. Alright, so they won't be in the mood for it, because of course, there a certain particulate interests at stake, like in any company, everybody wants to do his or her own thing.» (I1)

Small, independent units, like the private entities included in our analysis, which are able to operate somewhat outside of the administrative structures, reported far less structural difficulties or obstacles. In fact, outsourcing social media projects to such entities was 
considered a promising solution for stalling projects by employees within the core administration.

\section{Processes}

Hierarchy and bureaucracy were mentioned again and again as key obstacles to the speedy success of social media initiatives. Not only are rules and procedures experienced as strict and very comprehensive, the employees involved also tend to approve of formalized procedures - transparency and legitimacy were quoted again and again as crucial requirements of projects within the administration. Private entities reported hierarchical or bureaucratic obstacles only insofar as they needed to coordinate their activities with the core administration.

«Public administration tends to do everything correctly, legally clean, everything you communicate. Heaven forbid someone from outside would read our stuff before it's ready.» (I1)

"There is this feedback mechanism that exists between a query to us, feedback to the "house", maybe feedback to the agency leadership, a coordination process, and then feedback to the person who initiated the query. That is just a very complex and long process, such a typical public administration process, from which nobody can really deviate here.» (I3)

"It has been a long and difficult process, which has taken more than one and a half years now. You almost wonder why it takes so long.» (I4)

On the other hand, our interview partners recognized a certain tension between this culture and the requirements of fast-paced, dynamic social media.

«It [the implementation of social media] doesn't really fit into the internal structures, because a public administration is still hierarchically organized, but such an online-medium also requires speed.»(I1)

\section{Resources}

Possibly the element most often addressed in all interviews was the lack of necessary resources for social media initiatives - in some cases referring to IT capabilities, but predominantly to time and personnel restrictions. In times of austerity and budget cuts, social media do not enjoy an overriding priority within the administration. The research team was able to personally witness deteriorating office furniture and material and outdated IT equipment in some offices. Tight working schedules leave little room to experiment with 
social media. In one instance, an employee invested his free time and private IT resources to realize a project.

«Sure, it would be very easy. If only the resource question was settled, we wouldn't have any problems» (I1)

«There would be a press officer responsible for communication, but she wouldn't see herself in a position to add social media to her workload - because all of that takes a lot of time.» (I3)

«Our PCs aren't the best, the colleague responsible for the Internet works from home, he needs 5 minutes to upload something to the homepage. I need half an hour because the connection is so slow.»

Interview partners considered resource allocation a critical element of successful projects.

"The primary fear is that the processes are not clearly defined in the first place - who does what if there is additional work? - so you're prepared. But rather that something is simply developed again, that is then there, and somebody just has to do it.» (I1)

While private entities not necessarily have more resources at their disposal - rather in most cases, they are relatively small organizations - resource availability was much less of an issue in these instances. This may be due to the more formalized processes of budget and responsibility allocation within the core administration.

\section{Interpretation: Substantiation of the Research Framework}

After having developed a multi-level model of Social Media Readiness based on an explorative case study approach, we will now lay out how our findings relate to established theories of technology and innovation adaption. Table 2 provides an overview of the antecedents identified in our study and theories supporting and substantiating their impact on social media readiness. We found a distinct difference between the identified individual and organizational antecedents in that there is a lot of theoretical support for the former in the technology and innovation adoption literature, while the same does not hold for the organizational antecedents. In these instances, therefore, we extended the scope of our literature analysis until we were able to identify a theoretical body suitable to support our multi-level model: i.e. we propose that corporate or public entrepreneurship theories provide 
key insights that complement established findings in technology and innovation adoption and thereby allow for the development of a model of social media readiness that encompasses both individual and organizational antecedents.

Individual Level

\begin{tabular}{|l|l|l|}
\hline Construct & Theory & Studies \\
\hline Demographics & $\begin{array}{l}\text { Technology Acceptance; } \\
\text { Digital Divide }\end{array}$ & $\begin{array}{l}\text { Venkatesh et al. (2003), Venkatesh et } \\
\text { al. (2012); Hargittai (2007) }\end{array}$ \\
\hline Experience & $\begin{array}{l}\text { Technology Acceptance; } \\
\text { Online Trust }\end{array}$ & $\begin{array}{l}\text { Venkatesh et al. (2003), Venkatesh \& } \\
\text { Bala (2008); Venkatesh et al. (2012); } \\
\text { al. (1999) }\end{array}$ \\
\hline Performance Expectancy al. (2002); Hoffman et \\
\hline Effort Expectancy & Technology Acceptance & $\begin{array}{l}\text { Davis (1989); Venkatesh et al. (2003), } \\
\text { Venkatesh \& Bala (2008); Venkatesh }\end{array}$ \\
\hline Social Influence & Technology Acceptance
\end{tabular}

Table 2: Theoretical Support for Antecedents of Social Media Readiness 


\subsection{Individual Antecedents}

Two constructs lie at the core of all technology acceptance models: "Perceived Usefulness" and "Perceived Ease of Use". Davis (1989, p. 320) states: "people tend to use or not use an application to the extent they believe it will help them perform their job better". This notion was later incorporated into the UTAUT models, where it was re-phrased as "Performance Expectancy" (Venkatesh et al., 2003; 2012). Furthermore, Davis (1989, p. 320) notes: "even if potential users believe that a given application is useful, they may, at the same time, believe that the systems is too hard to use and that the performance benefits of usage are outweighed by the effort of using the application." This construct was rephrased "Effort Expectancy" in the UTAUT models. Technology acceptance models can be considered very well established, as numerous empirical tests have shown, these models explain approximately $40 \%$ of the variance in individuals' intention to use an ICT and actual usage (Venkatesh, \& Bala, 2008; Wang et al., 2003).

Technology acceptance models were also quick to acknowledge the impact of social interactions on users' intention to use an ICT. The UTAUT models therefore include "Social Influence" as a key driver: "Social influence is defined as the degree to which an individual perceives that important others believe that he or she should use the new system" (Venkatesh et al. 2003, p. 451). Furthermore, TAMs also suggest that demographics and use experience impact use intentions. In the initial UTAUT model, age, gender and experience are held to moderate the impact of Effort and Performance Expectancy on behavioral intentions (Venkatesh et al., 2003). In the more recent, extended UTAUT2 model, they are also proposed to moderate the effect of a number of additional acceptance drivers, such as hedonic motivation and habit (Venkatesh et al., 2012). The importance of demographics for the use of ICT has also been extensively studied and confirmed in the context of the "digital divide" debate (Van Dijk, 2006; Hargittai, 2007; Blank \& Reisdorf, 2012). Finally, online trust research was able to show that use experience impacts users' willingness to rely on new technologies and services (McKnight et al., 2002; Hoffman et al., 1999).

While self-efficacy and anxiety are not explicit elements of the UTAUT models, both are conceptualized to impact Perceived Ease of Use in the TAM3 model (Venkatesh \& Bala, 2008). “Computer self-efficacy refers to individuals' control beliefs regarding his or her personal ability to use a system" (Venkatesh \& Bala, 2008, p. 278). Computer anxiety, in turn, 
describes an affective component of users' decision making processes, it is defined "as an individual's apprehension, or even fear, when she/he is faced with the possibility of using computers" (Venkatesh, 2000, p. 349). While there is sufficient reason to believe that selfefficacy and anxiety both impact users' Effort Expectancy, our findings suggest that they exert a direct influence on individuals' social media readiness: Individuals with a strong belief in their ability to use ICT will be more proactive in engaging with social media projects. Also, users with high levels of concerns or anxiety regarding social media use (e.g. relating to questions of privacy and security) will tend to shy away from such projects independent of their judgment of social media's ease of use.

In summary, we find that the individual antecedents of social media readiness identified in our explorative study are strongly supported by technology acceptance theories, but also findings in digital divide and online trust research.

\subsection{Organizational Antecedents}

While technology acceptance theories draw heavily on social psychology, they do tend to neglect the organizational embeddedness of users (Granovetter, 1985). This deficit is partially offset by findings in the wider field of innovation diffusion. The Diffusion of Innovation (DOI) approach (Rogers, 1995) recognizes the importance of both organizational features, such as its structure, and management support. Organizational leaders' attitude towards innovations is held to be a key driver of organizational innovativeness, as is the size, complexity, formalization and centralization of the organizational structure. The latter, especially, also plays an integral part in Tornatzky and Fleischer's (1990) innovation diffusion model, which - aside from environmental factors and features of the innovation itself - considers organization size and structures as key antecedents of innovation diffusion. Both models have been applied to the study of ICT innovations. A meta-analysis by Hameed et al. (2012) finds that organizational size, formalization and centralization, resource availability, top management support affect the adoption of ICT innovations. Various studies have confirmed a positive impact of organization size on innovativeness (Goode \& Stevens, 2000; Eder \& Igbaria, 2001; Hsu et al., 2006; Pan \& Jang, 2008; Zhu et al., 2006). This impact may be due to higher resource availability in larger organizations. Therefore, some studies 
focused on this element, mostly confirming a positive impact of resource availability - such as competencies, technologies or organizational slack - on ICT innovation diffusion (Gibbs \& Kraemer, 2004; Goode \& Stevens, 2000; Hsu et al., 2006; Kuan \& Chau, 2001; Zhu et al., 2006). Top management support has also been confirmed as a driver of organizational innovation in a range of studies (Beatty et al., 2001; Chatterjee et al., 2002; Eder \& Igbaria, 2001).

Our literature analysis revealed that one innovation research subfield particularly focusses on organizational antecedents of innovation success: that of corporate entrepreneurship (CE). Sharma and Chrisman (1999, p. 18) define corporate entrepreneurship as "the process where by an individual or a group of individuals, in association with an existing organization, create a new organization or instigate renewal or innovation within that organization." In other words, CE focusses on entrepreneurial innovation developed within organizations which can lead to either new ventures or transformations of the organization (Zahra, 1991; Morris et al., 2008). According to Covin and Miles (1999) and Ireland and Webb (2007) such transformations can take the shape of strategic renewal, sustained regeneration, domain redefinition, organizational rejuvenation, and business model reconstruction. A key focus of corporate entrepreneurship research is the determinants and outcomes of Entrepreneurial Orientation and Behavior. In a widely accepted definition, Entrepreneurial Orientation is conceptualized as an organizational feature that encompasses dimensions such as risk taking, innovation, and proactivity (Covin \& Slevin, 1991; Covin \& Wales, 2011).

Research has come a long way in identifying antecedents of entrepreneurial innovations within existing organizations. In their seminal study, Hornsby, Kuratko \& Zahra (2002) identified five such antecedents: management support, discretion, rewards, resource availability and organizational boundaries. Management support is conceptualized as "the willingness of top-level managers to facilitate and promote entrepreneurial behavior, including the championing of innovative ideas and providing the resources people require to take entrepreneurial actions", work discretion/autonomy is defined as "top-level managers' commitment to tolerate failure, provide decision-making latitude and freedom from excessive oversight, and to delegate authority and responsibility to middle-level managers", rewards/reinforcement is defined as "developing and using systems that reward based on performance, highlight significant achievements, and encourage pursuit of challenging work", while resource availability is commonly operationalized as time availability 
("evaluating workloads to ensure that individuals and groups have the time needed to pursue innovations"), and, finally, organizational boundaries are understood as "precise explanations of outcomes expected from organizational work and development of mechanisms for evaluating, selecting, and using innovations" (Kuratko et al., 2005, pp. 703704).

With the exception of the "rewards" antecedent, we find a striking overlap of these elements with our findings. We suggest that the "rewards" element did not emerge from our data, because the public sector setting leaves little leeway to individually incentivize employee's innovativeness. The "organizational boundaries" antecedent comes very close to describing the "processes" factor identified in our analysis. In fact, corporate entrepreneurship literature commonly addresses the level of bureaucratization in conjunction with the "boundaries" construct. The only construct identified in our analysis not present in the Hornsby et al. (2002) model is that of size and complexity of the organizational "structure". Still, the antecedents identified in corporate entrepreneurship research have been successfully applied to non-profit and public sector settings (Morris et al., 2008; Kearny et al., 2009; Meynhardt \& Diefenbach, 2012). Morris and Jones (1999, p. 74) defined "public sector entrepreneurship" as "the process of creating value for citizens by bringing together unique combinations of public and/or private resources to exploit social opportunities".

We propose that findings from corporate/public entrepreneurship theory provide valuable insights to the study of social media readiness in public administrations because the introduction of social media in fact encompasses strategic, organizational and process innovations which affect the way public administrations provide value to their constituents. Thereby, more entrepreneurial organizations will be more ready to employ social media. Diffusion of innovation theories in conjunction with public entrepreneurship theories are therefore well-suited to substantiate organizational antecedents of social media readiness in public administrations. They complement our individual-level findings and allow for the derivation of a both theoretically and empirically grounded multi-level model of social media readiness in public administration. 


\section{Conclusion: The Way Ahead}

Our study developed a model of social media readiness that (a) includes antecedents of social media readiness both on an individual and organizational level, and (b) is tailored to the setting of public administrations, as it was derived from the perspectives and experiences of public employees responsible for and involved in social media initiatives. We propose this model as a framework for future research into social media readiness in public administration and its antecedents. The model is informed and substantiated by theories from information systems and innovation research. We find that technology acceptance, digital divide and trust theories strongly support the antecedents of social media readiness identified on the level of individual employees. Additionally, theories of innovation diffusion and public entrepreneurship contribute to our understanding of organizational antecedents of social media readiness.

Further research is necessary to test and refine the proposed model. To that end, the composition of the individual level antecedents should be tested with quantitative analysis. Thereby, the appropriateness of the underlying theories for a public sector setting should be scrutinized. We consider the organizational component of the model especially worthwhile for future research. The proposition that entrepreneurship theory may contribute to our understanding of social media readiness - because more entrepreneurial organizations would be better equipped to tackle the process, resources and value generation associated with the introduction of social media into administrative practices - requires further empirical analysis.

Finally, the multi-level model also requires further application, testing and refinement. A future conceptual step should consist in the differentiation of direct antecedents and moderating variables within the model. Also, an extension that includes contextual or environmental antecedents could further increase the explanatory power of the model. Here, again, DOI and TOE frameworks of innovation diffusion, and empirical applications of these frameworks to the adoption of ICT in the private sector, could inform future research.

As it is, we propose that our research has implications for both theory and practice. Theoretically, the developed model contributes to our understanding of social media readiness. It applies the construct to a public administration context, and it enriches current 
research by proposing a multi-level analysis of the phenomenon. This seems especially necessary given the organizational embeddedness of the social processes underlying social media readiness. As of today, e-government research largely lacks such a multi-dimensional and multi-level perspective (Grönlund, 2010; Titah \& Barki, 2006). Also, our model contributes to current theory by drawing from diverse, established strands of research and combining various previous findings into one comprehensive model.

For practice, our results provide insights for public administration leadership as to the drivers of social media readiness, both in regard to employee know-how and attitudes, and to organizational prerequisites. We have identified potential obstacles to successful social media initiatives based on case studies and actual experiences collected in social media projects. Given a certain reluctance and skepticism of many public administrations towards social media and their use for internal and external communication, our findings may help identify managerial options to increase social media readiness through organizational adjustments and personnel development measures. Also, our findings suggest promising approaches to social media initiatives, both in their composition and management. Given that many of our interview partners believe social media have the potential to provide a range of important benefits to their organizations - as do various researchers - we hope that our insights may contribute to the successful diffusion of new, interactive communication platforms in public administration. 


\section{References}

Ajzen, I. (1991). The Theory of Planned Behavior. Organizational behavior and human decision processes, 50(2), 179-211.

Albrecht, S., Kohlrausch, N., Kubicek, H., Lippa, B., Märker, O., Trénel, M., Vorwerk, V., et al. (2008). Electronic Participation of Citizens and the Business Community in eGovernment (Study on Behalf of the Federal Ministry of the Interior), 1-198.

Andersen, K. N., Medaglia, R., \& Henriksen, H. Z. (2012). Social media in public health care: Impact domain propositions. Government Information Quarterly, 29(4), 462-469.

Andersen, K. N., Medaglia, R., Vatrapu, R., Henriksen, H. Z., \& Gauld, R. (2011). The forgotten promise of e-government maturity: Assessing responsiveness in the digital public sector. Government Information Quarterly, 28(4), 439-445.

Bagozzi, R. P. (2007). The legacy of the technology acceptance model and a proposal for a paradigm shift. Journal of the Association for Information Systems, 8(4), 243-254.

Bannister, F., \& Connolly, R. (2012). The Great Theory Hunt: Does e-government really have a problem? Proceedings of the 2012 European Group of Public Administration eGovernment Study Group Annual Conference, Bergen, 1-29.

Beatty, R. C., Shim, J. P., \& Jones, M. C. (2001). Factors influencing corporate website adoption: a time-based assessment. Information \& Management, 38(6), 337-354.

Blank, G., \& Reisdorf, B. C. (2012). The Participatory Web. Information, Communication \& Society, 15(5), 537-554.

Chatterjee, D., Grewal, R., \& Sambamurthy, V. (2002). Shaping up for E-Commerce: Institutional Enablers of the Organizational Assimilation of Web Technologies. MIS Quarterly, 26(2), 65-89.

Compeau, D.R., \& Higgins, C.A. (1995). Application of social cognitive theory to training for computer skills. Information Systems Research, 6(2), 118-143.

Covin, J. G., \& Miles, M. P. (1999). Corporate Entrepreneurship and the Pursuit of Competitive Advantage. Entrepreneurship: Theory and Practice, 23(3), 47-63.

Covin, J. G., \& Slevin, D. P. (1991). A conceptual model of entrepreneurship as firm behavior. Entrepreneurship: Theory and Practice, 16(1), 7-25.

Covin, J. G., \& Wales, W. J. (2011). The Measurement of Entrepreneurial Orientation. Entrepreneurship: Theory and Practice, 36(4), 677-702.

Criado, J. I., \& Rojas-Martin, F. (2012). Strategies and realities of social media diffusion in the public sector. Evidence from the regional level of government in Spain. Proceedings of the 
European Group of Public Administration Annual Conference, Bergen Norway 5-8 September 2012, 1-20.

Davis, F. D. (1989). Perceived Usefulness, Perceived Ease of Use, and User Acceptance of Information Technology. MIS Quarterly, 13(3), 319-340.

Davis, F. D., Bagozzi, R. P., \& Warshaw, P. R. (1992). Extrinsic and intrinsic motivation to use computers in the workplace. Journal of Applied Social Psychology, 22(14), 1111-1132.

Denzin, N. (1983). Interpretative Interactionism. In Morgan, G. (ed.), Beyond Method: Strategies for Social Research. London: Sage.

Denzin N., \& Lincoln, Y. S. (1994). Introduction: Entering the field of qualitative research. In N. K. Denzin \& Y. W. Lincoln (eds.), Handbook of qualitative research: 1-17. Thousand Oaks: Sage.

DiMaggio, P., Hargittai, E., Neuman, R., \& Robinson, J. (2001). Social Implications of the Internet. Annual Review of Sociology, 27, 307-336.

Dodds, P. S., \& Watts, D. J. (2005). A generalized model of social and biological contagion. Journal of Theoretical Biology, 232(4), 587-604.

Ebbers, W. E., Pieterson, W. J., \& Noordman, H. N. (2008). Electronic government: Rethinking channel management strategies. Government Information Quarterly, 25(2), 181201.

Eder, L. B., \& Igbaria, M. (2001). Determinants of intranet diffusion and infusion. Omega, 29(3), 233-242.

Fishbein, M., \& Ajzen, I. (1975). Belief, attitude, intention and behavior: An introduction to theory and research. Reading, MA: Addison-Wesley.

Gauld, R., Goldfinch, S., \& Horsburgh, S. (2010). Do they want it? Do they use it? The "Demand-Side" of e-Government in Australia and New Zealand. Government Information Quarterly, 27(2), 177-186.

Gibbs, J. L., \& Kraemer, K. L. (2004). A Cross-Country Investigation of the Determinants of Scope of E-commerce Use: An Institutional Approach, Electronic Markets, 14(2), 124-137.

Glaser, B. G., \& Strauss, A. (1967). The Discovery of Grounded Theory: Strategies for Qualitative Research. New York: Aldine De Gruyter.

Goldenberg, J., Han, S., Lehmann, D. R., \& Hong, J. W. (2009). The Role of Hubs in the Adoption Process. Journal of Marketing, 73(2), 1-13.

Goode, S., \& Stevens, K. (2000). An analysis of the business characteristics of adopters and non-adopters of World Wide Web technology. Information Technology and Management, 1(1-2), 129-154. 
Granovetter, M. (1985). Economic Action and Social Structure: The Problem of Embeddedness. American Journal of Sociology, 91(3), 481-510.

Grönlund, Å. (2010). Ten Years of E-Government: The “End of History" and New Beginning. Electronic Government, Lecture Notes in Computer Science, 6228, 13-24.

Hameed, M. A., Counsell, S., \& Swift, S. (2012). A meta-analysis of relationships between organizational characteristics and IT innovation adoption in organizations. Information \& Management, 49, 218-232.

Hargittai, E. (2007). Whose Space? Differences Among Users and Non-Users of Social Network Sites. Journal of Computer-Mediated Communication, 13(1), Article 14.

Hargittai, E., \& Walejko, G. (2008). The Participation Divide - Content creation and sharing in the digital age. Information, Communication \& Society, 11(2), 239-256.

Heeks, R., \& Bailur, S. (2007). Analyzing e-government research: Perspectives, philosophies, theories, methods, and practice. Government Information Quarterly, 24(2), 243-265.

Höchtl, J., Parycek, P., \& Sachs, M. (2011). E-participation readiness of Austrian municipalities. Transforming Government: People, Process and Policy, 5(1), 32-44.

Hoffman, D. L., Novak, T. P., and Peralta, M. A. (1999). Information Privacy in the Marketspace: Implications for the Commercial Use of Anonymity on the Web. The Information Society, 15(2), 129-139.

Hong, S., \& Nadler, D. (2012). Which candidates do the public discuss online in an election campaign?: The use of social media by 2012 presidential candidates and its impact on candidate salience. Government Information Quarterly, 29(4), 455-461.

Hornsby, J. S., Kuratko, D. F., \& Zahra, S. A. (2002). Middle managers ' perception of the internal environment for corporate entrepreneurship: assessing a measurement scale. Journal of Business Venturing, 17(3), 253-273.

Hsu, P.-F., Kraemer, K. L., \& Dunkle, D. (2006). Determinants of E-Business Use in U.S. Firms. International Journal of Electronic Commerce, 10(4), 9-45.

Ireland, R. D., \& Webb, J. (2007). Strategic entrepreneurship: Creating competitive advantage through streams of innovation. Business Horizons, 50(1), 49-59.

Iyengar, R., Van Den Bulte, C., \& Valente, T. W. (2011). Opinion Leadership and Social Contagion in New Product Diffusion. Marketing Science, 30(2), 195-212.

Kearny, C., Hisrich, R. D., \& Roche, F. (2009). Public and private sector entrepreneurship: similarities, differences or a combination? Journal of Small Business and Enterprise Development, 16(1), 26-46. 
Kuan, K. K. Y., \& Chau, P. Y. K. (2001). A perception-based model for EDI adoption in small businesses using a technology-organization-environment framework. Information \& Management, 38(8), 507-521.

Kuratko, D. F., Ireland, R. D., Covin, J. G., \& Hornsby, J. S. (2005). A Model of Middle-Level Managers' Entrepreneurial Behavior. Entrepreneurship: Theory and Practice, 29(6), 699-717.

Lee, G., \& Kwak, Y. H. (2012). An Open Government Maturity Model for social media-based public engagement. Government Information Quarterly, 29(4), 492-503.

Lumpkin, G. T., \& Dess, G. G. (1996). Clarifying the Entrepreneurial Orientation Construct and Linking It to Performance. Academy of Management Review, 21(1), 135-172.

McKnight, D. H., Choudhury, V., and Kacmar, C. (2002). Developing and Validating Trust Measures for e-Commerce: An Integrative Typology. Information Systems Research, 13(3), 334-359.

Mergel, I. (2010). Gov 2.0 Revisited: Social Media Strategies in the Public Sector. PA Times, 33(3), 7.

Mergel, I. (2012). The Public Manager 2.0: Preparing the Social Media Generation for a Networked Workplace. Journal of Public Affairs Education, 18(3), 467-492.

Meynhardt, T., \& Diefenbach, F. E. (2012). What Drives Entrepreneurial Orientation in the Public Sector? Evidence from Germany's Federal Labor Agency. Journal of Public Administration Research and Theory, Advance Acccess, 1-32.

Molla, A., \& Licker, P. S. (2005). Perceived E-Readiness Factors in E-Commerce Adoption: An Empirical Investigation in a Developing Country. International Journal of Electronic Commerce, 10(1), 83-110.

Moore, G. C., \& Benbasat, I. (1991). Development of an Instrument to Measure the Perceptions of Adopting an Information Technology Innovation. Information Systems Research, 2(3), 192-222.

Morris, M. H., \& Jones, F. F. (1999). Entrepreneurship in established organizations: The case of the public sector. Entrepreneurship: Theory and Practice, 24(1), 71-91.

Morris, M. H., Kuratko, D. F., \& Covin, J. G. (2008). Corporate entrepreneurship and innovation ( $2^{\text {nd }}$ ed.). Mason, $\mathrm{OH}$ : Thomson South-Western.

Norris, D. F., \& Lloyd, B. A. (2006). The Scholarly Literature on E-Government: Characterizing a Nascent Field. International Journal of Electronic Government Research, 2(4), 40-56.

Oliveira, T., \& Martins, M. F. (2011). Literature Review of Information Technology Adoption Models at Firm Level. Information Systems Journal, 14(1), 110-121. 
Pan, M., \& Jang, W. (2008). Determinants of the adoption of enterprise resource planning within the technology-organization-environment framework: Taiwan's communications. Journal of Computer Information Systems, 48(3), 94-102.

Picazo-Vela, S., Gutiérrez-Martínez, I., \& Luna-Reyes, L. F. (2012). Understanding risks, benefits, and strategic alternatives of social media applications in the public sector. Government Information Quarterly, 29(4), 504-511.

Purvis, R. L., Sambamurthy, V., \& Zmud, R. W. (2001). The Assimilation of Knowledge Platforms in Organizations: An Empirical Study. Organization Science, 12(2), 117-135.

Rafferty, A. E., Jimmieson, N. L., \& Armenakis, A. A. (2013). Change Readiness: A Multilevel Review. Journal of Management, 39(1), 110-135.

Rogers, E. M. (1995). Diffusion of Innovations. An integrated approach to communication theory and research. New York, Free Press.

Rossel, P., \& Finger, M. (2007). Conceptualizing e-Governance. (T. Janowski \& T. A. Pardo, Eds.) Proceedings of the 1st international conference on Theory and practice of electronic governance ICEGOV 07, 399-407.

Sharma, P., \& Chrisman, J. J. (1999). Toward a reconciliation of the definitional issues in the field of corporate entrepreneurship. Entrepreneurship: Theory and Practice, 23(3), 11-27.

Strauss, A. L., \& Corbin, J. (1998). Basics of Qualitative Research: Techniques and Procedures for Developing Grounded Theory (2nd ed.). Thousand Oaks: Sage.

Stromer-Galley, J., \& Foot, K. A. (2002). Citizen Perceptions of Online Interactivity and Implications for Political Campaign Communication. Journal of Computer-Mediated Communication, $8(1), 0$.

Taylor, S., \& Todd, P. (1995). Assessing IT Usage: The Role of Prior Experience. MIS Quarterly, 19(4), 561-570.

Teo, H. H., Wei, K. K., \& Benbasat, I. (2003). Predicting Intention to Adopt Interorganizational Linkages: An Institutional Perspective. MIS Quarterly, 27(1), 19-49.

Thompson, R. L., Higgins, C.A., \& Howell, J. M. (1991). Personal computing: Toward a conceptual model of utilization. MIS Quarterly, 15(1), 124-143.

Titah, R., \& Barki, H. (2006). E-Government Adoption and Acceptance: A Literature Review. International Journal of e-Government Research, 2(3), $23-57$.

Tornatzky, L. G., \& Fleischer, M. (1990). The Process of Technology Innovation. Lexington (MA), Lexington Books.

Van Dijk, J. (2006). Digital divide research, achievements and shortcomings. Poetics, 34(4-5), 221-235. 
Venkatesh, V., \& Bala, H. (2008). Technology Acceptance Model 3 and a Research Agenda on Interventions. Decision Sciences, 39(2), 273-315.

Venkatesh, V., \& Davis, F. D. (2000). A Theoretical Extension of the Technology Acceptance Model: Four Longitudinal Field Studies. Management Science, 46(2), 186-204.

Venkatesh, V., Morris, M. G., Davis, G. B., \& Davis, F. D. (2003). User acceptance of information technology: Toward a unified view. MIS Quarterly, 27(3), 425-478.

Venkatesh, V., Thong, J. Y. L., \& Xu, X. (2012). Consumer Acceptance and Use of Information Technology: Extending the Unified Theory of Acceptance and Use of Technology. MIS Quarterly, 36(1), 157-178.

Wang, Y., Wang, Y., Lin, H., \& Tang, T. (2003). Determinants of user acceptance of internet banking: an empirical study. International Journal of Service Industry Management, 14(5), 501-519.

Watts, D. J., \& Dodds, P. S. (2007). Influentials, Networks, and Public Opinion Formation. Journal of Consumer Research, 34(December), 441-458.

White, C. S. (1997). Citizen Participation and the Internet: Prospects for Civic Deliberation in the Information Age. Social Studies, 88(1), 23-28.

Zahra, S. A. (1991). Predictors and financial outcomes of corporate entrepreneurship: An exploratory study. Journal of Business Venturing, 6(4), 259-285.

Zhu, K., Dong, S., Xu, S. X., \& Kraemer, K. L. (2006). Innovation diffusion in global contexts: determinants of post-adoption digital transformation of European companies. European Journal of Information Systems, 15(6), 601-616.

Zhu, K., Kraemer, K. L., \& Xu, S. X. (2003). Electronic business adoption by European firms: a cross-country assessment of the facilitators and inhibitors. European Journal of Information Systems, 12(4), 251-268. 